- Monogràfic -

\title{
CONTENDING PHILOSOPHICAL FOUNDATIONS IN INTERNATIONAL WILDLIFE LAW: A DISCOURSE ANALYSIS OF CITES AND THE BERN CONVENTION
}

\author{
DAVID RODRÍGUEZ GOYES \\ Postdoctoral researcher \\ Department of Criminology and Sociology of Law \\ University of Oslo \\ (Norway) \\ d.r.goyes@jus.uio.no
}

Date of Reception: March $5^{\text {th }} 2021 /$ Date of Acceptance: April 14 2021

\begin{abstract}
Most analyses of international wildlife law (IWL) focus on the specifics of implementing particular policies, while there is less engagement with the fundamental philosophies underpinning international conventions. In this article, I argue that a philosophical analysis can achieve a deeper understanding of IWL by helping to identify, assess and compare worldviews reflected in these instruments. Additionally, a philosophical analysis can make visible how international wildlife conventions shape human perceptions of and attitudes towards nature. Based on these premises, I subject two international wildlife conventions that are central to wildlife management in Europe, namely, the Bern Convention on the Conservation of European Wildlife and Natural Habitats and the Convention on International Trade in Endangered Species of Wild Fauna and Flora (CITES), to philosophical scrutiny. I argue, first, that the philosophical underpinnings of these instruments are in contention, indicating that their policies might well counteract each other. Second, I postulate that the broad significance of this contention is that the resulting
\end{abstract}


ambivalence when IWL instruments are involved in the same conversation and about the same territoriality results in such high discretional powers for states that they stop being bounded by the conventions' substratum and can limit themselves to only following the formalities.

RESUM: La majoria de les anàlisis del Dret Internacional de la Vida Silvestre (IWL, per les seves sigles en anglès) se centren en els aspectes específics de l'aplicació de determinades polítiques, mentre que hi ha menys compromís amb les filosofies fonamentals que apuntalen els convenis internacionals. En aquest article, sostinc que una anàlisi filosòfica pot aconseguir una comprensió més profunda del Dret Internacional de la Vida Silvestre en ajudar a identificar, avaluar i comparar les visions del món reflectides en aquests instruments. A més, una anàlisi filosòfica pot visibilitzar com els convenis internacionals sobre la vida silvestre modelen les percepcions i actituds humanes cap a la natura. Partint d'aquestes premisses, sotmeto a l'escrutini filosòfic dos convenis internacionals sobre la vida silvestre essencials per a la seva gestió a Europa, a saber, el Conveni de Berna relatiu a la conservació de la vida silvestre i del medi natural a Europa, i la Convenció sobre el Comerç Internacional d'Espècies Amenaçades de Flora i Fauna Silvestres (CITES, per les seves sigles en anglès). Sostinc, en primer lloc, que els fonaments filosòfics d'aquests instruments són contradictoris, la qual cosa dificulta la seva aplicació simultània per les parts signants. En segon lloc, sostinc que el significat general d'aquesta contenció és que l'ambivalència resultant quan els instruments de la IWL estan implicats en la mateixa conversació i sobre la mateixa territorialitat dona lloc a poders discrecionals fortament discrecionals per als Estats fins i tot perquè deixen d'estar limitats pels convenis i poden limitar-se únicament a seguir les formalitats.

RESUMEN: La mayoría de los análisis del Derecho internacional de la Vida Silvestre (IWL por sus siglas inglesas) se centran en aspectos específicos de la aplicación de determinadas políticas, mientras que hay un menor compromiso con los fundamentos filosóficos que sustentan los convenios internacionales. En este artículo, sostengo que un análisis filosófico puede lograr una comprensión más profunda del IWL al ayudar a identificar, evaluar y comparar las visiones del mundo reflejadas en estos instrumentos. Además, un análisis filosófico puede hacer visible 
el modo en que los convenios internacionales sobre fauna y flora silvestres configuran las percepciones y actitudes humanas hacia la naturaleza. Partiendo de estas premisas, someto a un escrutinio filosófico dos convenios internacionales sobre la vida silvestre que son fundamentales para la gestión de la misma en Europa, a saber, el Convenio de Berna sobre la Conservación de la Vida Silvestre y el Hábitat Natural de Europa y la Convención sobre el Comercio Internacional de Especies Amenazadas de Fauna y Flora Silvestres (CITES). En primer lugar, sostengo que los fundamentos filosóficos de dichos instrumentos están en disputa, lo que indica que sus políticas bien podrían contrarrestarse entre sí. En segundo lugar, postulo que el significado general de esta contención es que la ambivalencia resultante cuando los instrumentos de la LBI están implicados en la misma conversación y sobre la misma territorialidad da lugar a poderes discrecionales tan elevados para los Estados que dejan de estar limitados por el sustrato de las convenciones y pueden limitarse a seguir únicamente las formalidades.

KEY WORDS: Bern Convention - CITES - Environmental philosophy International wildlife law.

PARAULES CLAU: Conveni de Berna - CITES - Filosofia ambiental — Dret Internacional de la Vida Silvestre.

PALABRAS CLAVE: Convenio de Berna - CITES — Filosofía ambiental — Derecho Internacional de la Vida Silvestre.

TABLE OF CONTENTS: I. Introduction. II. Background: Socio-Legal Analyses Of Cites And The Bern Convention. III. Theory: The Construction and Deconstruction of Reality Through Philosophy and Language. Methods. V. Context: International Environmental Law. 1. International Treaties on Wildlife Species, Ecosystems and Biodiversity. VI. Findings: Two Interacting Conventions at Odds. 1. Ontology: Individual State Sovereignty Versus Regional Cooperation. 2. Axiology: Species and Trade Vis-à-vis Ecosystems and Subsistence. 3. Epistemology: Quantitative Science Versus Instrumental Diplomacy. VII. Discussion and Conclusion: Fundamental Contradictions, Political Philosophy and Future Challenges. Acknowledgements. References. 


\section{INTRODUCTION}

Crutzen coined the term "Anthropocene" to characterize the current era in which humans are the main shapers of the biosphere. ${ }^{1}$ Vetlesen further describes it as "the shift from the geological epoch called the Holocene to the Anthropocene...due to the fact that the influence of humanity now outweighs the impact of the most powerful natural forces on the functioning of the earth system". ${ }^{2}$ These definitions have the inherent negative connotation that humanity's activity has adversely impacted nature. Indeed, scientists have associated it with the ongoing sixth mass extinctionalso called the Anthropocene extinction-in which human acts and omissions are propelling environmental disorganisation and the loss of a significant segment of the world's biodiversity. ${ }^{3}$ According to van Uhm, the sixth mass extinction involves the yearly extermination of "between 17,000 and 100,000 species" by humans, who are "killing species, introducing non-native species, fragmenting habitats, spreading pathogens, co-opting resources and changing global climate". ${ }^{4}$ The consequences of the Anthropocene are as dramatic as the label "the sixth mass extinction" indicates: a "comparison of current global biomass with prehuman values...demonstrates the impact of humans on the biosphere....The present day biomass is approximately sevenfold lower". ${ }^{5}$ In addition, "an overall decline of $68 \%$ in [wildlife] population sizes between 1970 and 2016" has been recorded. ${ }^{6}$

\footnotetext{
${ }^{1}$ P. J. Crutzen, "The 'Anthropocene", in E. Ehlers and T. Krafft (eds.), Earth System Science in the Anthropocene, Springer. New York, 2006. See, also, A. Brisman and N. South, "Autosarcophagy in the Anthropocene and the obscenity of an epoch", in C. Holley and C. Shearing (eds.), Criminology and the Anthropocene, Routledge. London, 2018, pp. 25-49; R. Sollund, G. Larsen and M. Tønnesen (eds.), Hvem er villest $i$ landet her? Menneskets brutalitet mot dyr i en verden uten villmark [Who is the most savage in this country? Humans' brutality against animals in a world without wild zones]. Scandanavian Academic Press. Oslo, 2013.

2 A. J. Vetlesen, Cosmologies of the Anthropocene: Panpsychism, Animism, and the Limits of Posthumanism, Routledge. London, 2019, pp. 3-4.

${ }^{3}$ M. J. Lynch, M. A. Long, K. L. Barret and P. B. Stretesky, "Is it a crime to produce ecological disorganization?" in British Journal of Criminology, num 53, 2013, pp. 997-1016. $<$ doi:10.1093/bjc/azt051>.

${ }^{4}$ D. van Uhm, The Illegal Wildlife Trade, Springer. New York, 2016, p. 19.

5 Y. M. Bar-On, R. Phillips and R. Milo, "The biomass distribution on earth", in Proceedings of the National Academy of Sciences, num 115, 2018, p. 6508. <doi:10.1073/pnas.1711842115>.

6 M. Grooten and R. E. A. Almond, Living Planet Report: Bending the Curve of Biodiversity Loss, World

Wildlife

Fund,

2020,

p.

6.
} 
Various conventions that are part of international wildlife law (IWL), ${ }^{7}$ although not directly referencing the sixth mass extinction, articulate a concern over the pace of destruction and the consequences of the Anthropocene. Among them, the Convention on International Trade in Endangered Species of Wild Fauna and Flora (CITES), ${ }^{8}$ one of the most important treaties worldwide regulating the commerce of individuals of protected species, states that there is "urgency [in] taking action" to protect wild fauna and flora "against over-exploitation". ${ }^{9}$ Similarly, the Convention on the Conservation of European Wildlife and Natural Habitats (Bern Convention), ${ }^{10}$ the most important European convention in the area of habitat and species protection, asserts that many species "are being seriously depleted....and some of them are threatened with extinction."11

Despite such declarations of good will, experts have indicated that IWL in general, and CITES and the Bern Convention in particular, have fallen short in their declared goals of protecting ecosystems and wildlife fauna and flora. ${ }^{12}$ While admitting that these conventions are far from being the absolute-or even the primary-means of solving the global wildlife crisis, these experts point variously to the source of the instruments' shortcomings. For some, the problem lies in the texts and subsequent decisions of the conventions, which they base on doctrinal analyses. For others the lack of compliance by participating nations poses the greatest obstacle, a conclusion they base on empirical data of the day-to-day dynamics behind the inadequate compliance of nation-states. Very few have used philosophical tools to investigate

\footnotetext{
<https://f.hubspotusercontent20.net/hubfs/4783129/LPR/PDFs/ENGLISH-FULL.pdf>. [Retrieved on 24 May 2021].

${ }^{7}$ A. Trouwborst et al. define international wildlife law as the set of international wildlife agreements and their "evolving set of nonbinding instruments, such as Conference of the Parties (COP) decisions and actions plans". See "International wildlife law: Understanding and enhancing its role in conservation", in BioScience, num 67, 2017, p. 784. <doi:10.1093/biosci/bix086>.

${ }^{8}$ CITES was signed in 1973 and came into force in 1975.

${ }^{9}$ CITES, Convention text, 1983, preamble. <https://cites.org/eng/disc/text.php\#texttop> [Retrieved on 26 February 2021].

10 The Bern Convention was signed in 1979 and came into force in 1982.

11 Council of Europe, Convention on the Conservation of European Wildlife and Natural Habitats, 1979 , preamble. $<$ https://www.coe.int/en/web/conventions/full-list//conventions/rms/0900001680078aff>. [Retrieved on 24 May 2021].

12 See section II. Background: Socio-Legal Analyses of CITES and Bern Conventions. See, also, "Failures of Environmental Protection", Georgetown Environmental Law Review, num 16, 2004, p. 16.
} 
how the fundamentals of the conventions produce unfavourable consequences for wildlife.

In this article, I undertake an innovative, in-depth analysis of the texts of CITES and the Bern Convention and their recommendations and resolutions, from a philosophical standpoint. As I explain in section 4 (Methods), the main reason for choosing CITES and the Bern Convention as the focus of this study is that even while these instruments are binding and central in the regulation of wildlife management in most European countries, their axiological bases are in diametrical opposition with each other regarding where they place the locus of value in nature. ${ }^{13}$ While the Bern Convention places it on ecosystems, CITES assigns it to species. Consequently, I explore whether such a philosophical contention is the cause of the limitations scholars have identified of the suboptimal functioning of the conventions. I do so by investigating if other philosophical components of CITES and the Bern Convention are also misaligned $^{14}$ and whether, despite them operating simultaneously in European countries, the fundamental messages they send are ambiguous vis-à-vis each other, thereby generating policy problems for signatories.

The main purpose of this article is to assess the philosophical bases of CITES and the Bern Convention. This is, first, of interest as pure research, which "address[es] a conceptual problem that does not bear directly on any practical situation... [but] only improves the understanding of a community of researchers". ${ }^{15}$ I explore how diverse voices (in this case CITES and the Bern Convention) operating in the same field (IWL) and in the same territory (Europe) engage in a common debate about the management of wildlife. However, this study also reports practical relevance in that "it addresses a conceptual problem that does have practical consequences" because of the way those voices frame the debate about wildlife and states' management plans.

\footnotetext{
${ }^{13}$ M. Bowman, P. Davies and C. Redgwell, Lyster's International Wildlife Law, Cambridge University Press. Cambridge, 2010. For a detailed explanation of locus of value, see section II. "Background: Socio-Legal Analyses of CITES and the Bern Convention".

${ }^{14}$ For a definition of the concepts axiology, epistemology and ontology, see section III.1. "Language, Philosophy and the Law".

${ }^{15}$ W. C. Booth et al., The Craft of Research, Chicago. The University of Chicago Press, 2016, p. 57.
} 
I begin by reviewing the most relevant socio-legal analyses of CITES and the Bern Convention and their important contributions to understanding the on-the-ground failures of these conventions. I also show that most of these analyses do not address the fundamental taken-for-granted assumptions about the world that undergird the conventions. To expose these worldviews that inform international law, I combine philosophical insights with discourse analysis theory, a framework that I present in section three. Next, I present a brief description of the methods I used for this study. In the fifth section, I provide the broad contextual background of the Bern Convention and CITES. Among other things, I include a brief description of the international environmental law (IEL) regime. In the sixth section, I present the core finding of this study: that the Bern Convention and CITES are misaligned ontologically, axiologically and epistemologically, indicating that their derived policies potentially counteract each other. I conclude the article by discussing the broad, applied significance of this study: that the ambivalence of these two IWL instruments, which participate in the same conversation and have the same territoriality, provides such high discretional powers for states that they stop being bounded by the conventions' substratum and can limit themselves to adhering only the formalities. Consequently, I argue that besides the doctrinal and empirically based explanations for the suboptimal functioning of CITES and the Bern Convention, another cause is the extensive latitude the conventions' ambivalence allows the states.

\section{BACKGROUND: SOCIO-LEGAL ANALYSES OF CITES AND THE BERN CONVENTION}

There are multiple sociological, legal and socio-legal analyses of how well IWL protects ecosystems and species. Most of these studies are focused on the specifics of implementing particular policies, and as a community, wildlife lawyers have engaged less with the fundamental philosophies underpinning longstanding regimes than have other branches of environmental law.

Analyses of IWL can be divided into three categories: First, those that see it as fully functional. Lewis, for example, asserts that CITES offers the necessary legal 
infrastructure to both conserve wildlife and have a positive impact on rural livelihoods. ${ }^{16}$ The second category of studies comprises those that critique certain components of specific IWL instruments while lauding other aspects and those that identify how IWL regulations are informed by intrinsic tensions such as being simultaneously positive in one regard while detrimental in another. For instance, Maunder, Higgens and Culham argue that the Bern Convention is useful in identifying the wildlife plant species most threatened in Europe and in outlining adequate measures to protect them but that it is disconnected from the local context where plant species are impacted. ${ }^{17}$ Highlighting the tensions informing CITES, Stoett argues that while its Western, centralised decision-making can be seen as important "because the value of biodiversity must supersede that of cultural tradition and economic opportunity", it can also be read as a phenomenon that "fails to take into account the need for international trade in order to sustain local enthusiasm for trade limitations in southern states and amongst indigenous communities in the south". ${ }^{18}$ The third category of analysis are those that critique the outcomes of IWL. Some such studies (examples given below) focus on the texts of the conventions and subsequent decisions and others focus on the inadequacy of national implementation.

Clearly the effectiveness of CITES and the Bern Convention for the protection of ecosystems and wildlife species is contested. It is true that some scholars have highlighted the effectiveness of these instruments, but during the past decades, a significant number of experts have noted the negative outcomes of the two conventions. Most of the analyses of CITES discuss the ineffectiveness of its protective measures, critiquing its failure to enforce its regulations broadly and

\footnotetext{
${ }^{16}$ M. G. Lewis, "CITES and rural livelihoods: The role of CITES in making wildlife conservation and poverty reduction mutually supportive", in Journal of International Wildlife Law and Policy, num 12, 2009, pp. 248-275. <doi:10.1080/13880290903433014>.

17 M. Maunder, S. Higgens and A. Culham, "The effectiveness of botanic garden collections in supporting plant conservation: A European case study", in Biodiversity and Conservation, num 10, iss 3, 2001, pp. 383-401.

18 P. Stoett, "The International Regulation of Trade in Wildlife: Institutional and Normative Considerations", in International Environmental Agreements, num 2, iss 2, p. 193.
} 
effectively. ${ }^{19}$ For instance, Baker associates the low compliance rate with the CITES mandate with the high cost of the strategies that the convention advises: several countries experience "significant difficulty in implementation due to domestic financial limitations". ${ }^{20}$ Graham offers a similar opinion based on her analysis of the "gap between international intent and domestic application of CITES". ${ }^{21}$ Bowman shows that while CITES references trade and conservation, national authorities prioritize trade to the determent of effective conservation. ${ }^{22}$ Heinen and Chapagain, in turn, blame the "complex legal requirements that it [CITES] imposes on its parties" for the failure of CITES to protect species. ${ }^{23}$ Bauer, Nowell, Sillero-Zubiri and Macdonald find that CITES bases its decisions on incomplete information and that political considerations trump demonstrated conservation needs. ${ }^{24}$ Similarly, Sollund has critiqued CITES extensively for not caring about animal welfare and for placing economic interests above the protection of animals from trafficking and abuse. ${ }^{25}$ Using ivory trafficking as her case, Persaud demonstrates that CITES offers little protection for animal species because it lacks incentives for compliance and fails to

\footnotetext{
${ }^{19}$ J. Hutton and B. Dickson, "Introduction", in. J. Hutton and B. Dickson (eds.), Endangered Species Threatened Convention: The Past, Present and Future of CITES, Routledge. London, 2000.

$20 \mathrm{~J}$. E. Baker, "A substantive theory of the relative efficiency of environmental treaty compliance strategies: The case of CITES", in Journal of International Wildlife Law and Policy, num 2, 1999, p. 4. <doi:10.1080/13880299909353918>.

${ }^{21} \mathrm{~K}$. Graham, "International intent and domestic application of the Convention on International Trade in Endangered Species of Wild Fauna and Flora (CITES): The case of the ocelot (Leopardus pardalis)", in Journal of International Wildlife Law and Policy, num 20, 2017, p. 288. $<$ doi:10.1080/13880292.2017.1403797>.

${ }_{22} \mathrm{M}$. Bowman, "Conflict or compatibility? The trade, conservation and animal welfare dimensions of CITES", in Journal of International Wildlife Law and Policy, num 1, 1998, pp. 9-63. $<$ doi:10.1080/13880299809353883>.

${ }^{23} \mathrm{~J}$. T. Heinen and D. P. Chapagain, "On the expansion of species protection in Nepal: Advances and pitfalls of new efforts to implement and comply with CITES", in Journal of International Wildlife Law and Policy, num 5, 2002, p. 235. <doi:10.1080/13880290209354012>.

${ }^{24} \mathrm{H}$. Bauer, K. Nowell, C. Sillero-Zubiri and D. W. Macdonald, "Lions in the modern arena of CITES", in Conservation Letters, num 11, 2018, p. e12444. <doi.org/10.1111/conl.12444>.

${ }^{25} \mathrm{R}$. Sollund, "Expressions of speciesism: The effects of keeping companion animals on animal abuse, animal trafficking and species decline", in Crime, Law and Social Change, num 55, 2011, pp. 437-451. <doi:10.1007/s10611-011-9296-3>; R. Sollund, "Animal trafficking and trade: Abuse and species injustice", in R. Walters, D. Westerhuis and T. Wyatt (eds.), Emerging Issues in Green Criminology, Palgrave Macmillan. London, 2013, pp. 72-92; R. Sollund and J. Maher, The Illegal Wildlife Trade: A Case Study Report on the Illegal Wildlife Trade in the United Kingdom, Norway, Colombia and Brazil. A Study Compiled as Part of the EFFACE Project, EFFACE. Oslo, 2015; R. Sollund, The Crimes of Wildlife Trafficking: Issues of Justice, Legality and Morality, Routledge. London, 2019.
} 
punish breaches. ${ }^{26}$ Korwin, Denier, Lieberman and Reeve emphasize that while CITES's mandate is premised on differentiating between legally and illegally traded species, in practice it is often difficult to make this differentiation of species. ${ }^{27}$ Finally, Harrop and Bowles demonstrate that the multilateral trade regime dominated by the World Trade Organisation and IEL such as CITES are often at odds with each other, "mak[ing] it extremely difficult to develop or maintain animal welfare standards in the international and, to some extent, in the national context". ${ }^{28}$

While there are fewer socio-legal studies of the Bern Convention, scholars have also critiqued its inability to protect ecosystems. Trouwborst, Fleurke and Linnell point to the vagueness of its content and the ineffectiveness of its protective measures, which they blame on the political discretion that the steering committee has. ${ }^{29}$ Sollund described the Standing Committee (SC) of the Convention, which is in charge of ensuring compliance, as "a political rather than a legal body" that fails to secure the implementation of the convention's mandates. ${ }^{30}$ Similarly, Epstein found that the European Union uses the Bern Convention to advance its political agenda,

${ }^{26} \mathrm{~S}$. Persaud, "Losing our 'CITES' on the 'traffic': How taxing ivory trafficking can save the African elephant from its bloody extinction", in Journal of International Wildlife Law and Policy, num 20, 2017, pp. 295-320. <doi:10.1080/13880292.2017.1403813>.

${ }^{27}$ S. Korwin, L. Denier, S. Lieberman and R. Reeve, "Verification of legal acquisition under the CITES convention: The need for guidance on the scope of legality", in Journal of International Wildlife Law and Policy, num 22, 2019, pp. 274-304. <doi:10.1080/13880292.2019.1695718>. See, also, D. R. Goyes and R. Sollund, "Contesting and contextualising CITES: Wildlife trafficking in Colombia and Brazil", in International Journal for Crime, Justice and Social Democracy, num 5, 2016, pp. 87-102.

${ }^{28} \mathrm{~S}$. Harrop and D. Bowles, "Wildlife management, the multilateral trade regime, morals and the welfare of animals", in Journal of International Wildlife Law and Policy, num 1, 1998, p. 93. <doi:10.1080/13880299809353884>. See, also, A. Kothari and R. V. Anuradha, "Biodiversity and intellectual property rights: Can the two co-exist?" in Journal of International Wildlife Law and Policy, num 2, 1999, pp. 204-223. <doi:10.1080/13880299909353928>; N. South, "The contested planet: Global green criminology and environmental crime in transnational context", in T. Spapens, R. White and W. Huisman (eds.), Environmental Crime in Transnational Context, Routledge. London, 2016; N. South, "Free trade agreements, private courts and environmental exploitation: Disconnected policies, denials and moral disengagement", in International Journal for Crime, Justice and Social Democracy, num 5, 2016, pp. 45-59.

${ }^{29}$ A. Trouwborst, F. M. Fleurke and J. D. C. Linnell, "Norway's wolf policy and the Bern Convention on European Wildlife: Avoiding the 'manifestly absurd'", in Journal of International Wildlife Law and Policy, num 20, 2017, pp. 155-167.

${ }^{30}$ R. Sollund, "Wildlife management, species injustice and ecocide in the Anthropocene", in Critical Criminology, num 28, 2019, p. 14. <doi:10.1007/s10612-019-09469-1>. See, also, Trouwborst et al., "Norway's wolf policy..." cit. 
despite the negative repercussions this has for species protection. ${ }^{31}$ Researchers have also found that, like CITES, the Bern Convention's "transposition of general obligations from international agreements into local legislation systems may be a critical point of weakness in the biodiversity conservation policy process". ${ }^{32}$

While these studies point out important flaws in the Bern Convention's and CITES's abilities to protect ecosystems and species, respectively, they overlook the important contribution philosophy can make to an evaluation of these conventions. Even scholars in disciplines aligned with normative and philosophical analyses of environmental matters, such as environmental philosophy, have neglected to conduct broad philosophical explorations of IWL. ${ }^{33}$ Justice analyses dominate most of these studies to the point of blindness to other areas of relevant philosophical inquiry. In short, analyses of IWL lack a systematic engagement with philosophical inquiry to their determent.

One of the few examples of a deep philosophical analysis of IWL is the one advanced by Bowman, Davies and Redgwell. They argue that whereas IWL has not evolved along a grand philosophical trajectory, the recognition that nature has value, and that it therefore must be protected, underpins the philosophical deliberations of IWL. ${ }^{34}$ For them, there are two main points of contestation. First, the kind of value nature has. Most IWL instruments assign instrumental (or commodity) value to nature, that is, nature is of use to humans. Bowman and colleagues argue that the primacy of instrumental value in IWL has resulted in most of it being anthropocentric, which has led to extensive exploitation of the environment. More recently, particularly with the implementation of the 1992 Convention on Biological Diversity, IWL has incorporated an aesthetic consideration of the inherent value of nature. Finally, a few

\footnotetext{
31 Y. Epstein, "The Habitats Directive and Bern Convention: Synergy and dysfunction in public International and EU law", in Georgetown Environmental Law Review, num 26, 2014, pp. 139-173.

32 V. Sazatornil et al., "Top-down dilution of conservation commitments in Europe: An example using breeding site protection for wolves", in Biological Conservation, num 237, 2019, p. 198. $<$ doi.org/10.1016/j.biocon.2019.06.027>.

${ }^{33}$ Environmental philosophy is defined by C. J. Barrow and J. A. Matthews as "the study of how the environment is understood and valued". See "Environmental philosophy", in Encyclopedia of Environmental Change, 2014. <doi.org/10.4135/9781446247501.n1314>.

${ }^{34}$ Bowman et al., Lyster's... cit.
} 
IWL instruments have tentatively acknowledged the intrinsic (or moral) value that the environment possesses, regardless of its utility for humans. The first explicit recognition of intrinsic value is evident in the preamble to the Bern Convention.

The second point of contestation Bowman et al. identify in IWL regards nature's locus of value. IWL has situated it variously, but generally the focus has been on preserving species and ecosystems/basic ecological processes..$^{35} \mathrm{CITES}$ focuses on species, while the Bern Convention focuses on ecosystems, viewing them as "superorganisms" ${ }^{36}$ For Bowman et al., both stances are problematic. First, because allocating value to species lacks "concreteness" and, second, assigning value to ecosystems leaves no way to identify and demarcate. ${ }^{37}$

Bowman et al.'s analysis of the axiology of IWL demonstrates that a philosophical analysis makes possible the identification of the fundamental issues underpinning the instruments comprising IWL and the identification of fundamental issues hindering effective protection of the environment. Similarly illustrative of the usefulness of philosophy in evaluating IWL is the study of Le, who explores how CITES actively promotes a neoliberal understanding of nature. ${ }^{38}$ In this article, I move forward the work of Bowman et al. and Le by unveiling the philosophical underpinnings of the Bern Convention and CITES through a comparative analysis, to argue that in addition to the doctrinal and empirically based explanations for the suboptimal functioning of CITES and the Bern Convention, the extensive latitude the conventions' ambivalence allows states is also fundamentally problematic. To begin, in the next section I discuss the conceptual and theoretical framework of this study and show how analysing international legal instruments from a philosophical perspective makes it possible to identify, assess and compare the worldviews reflected in these instruments.

\footnotetext{
${ }^{35}$ Bowman et al., Lyster's... cit., p. 73. See, also, A. Gillespie, International Environmental Law, Policy, and Ethics, Oxford University Press. Oxford, 2014 (2nd edition).

${ }^{36}$ Bowman et al., Lyster's... cit., p. 72.

${ }^{37}$ Bowman et al., Lyster's... cit., p. 73.

${ }^{38} \mathrm{~T}$. Le, "CITES as global governance: Paths to consensus and defining nature through uncertainty", in Journal of International Wildlife Law and Policy, num 22, 2019, pp. 115-144. <doi:10.1080/13880292.2019.1629176>.
} 


\section{THEORY: THE CONSTRUCTION AND DECONSTRUCTION OF REALITY THROUGH PHILOSOPHY AND LANGUAGE}

Definitions of philosophy usually fall into two categories: philosophy as the contemplation of ultimate meaning and philosophy as the evaluation of reason. ${ }^{39} \mathrm{By}$ synthetizing those two categories, I understand philosophy to be the systematic and logical assessment of ideas and the reasoning and categories we use to think about ultimate questions. A fundamental problem for workaday scientists is associated with how to incorporate philosophical reasoning into everyday science. Of relevance for this study are the philosophical constructs of "necessary preconditionalism" and "hierarchicalism". While the former requires that the assumptions on which humans build theories (scientific or everyday life theories) are identified, the second necessitates interlinking and hierarchizing the components of diverse philosophical areas.

Discourse analysis is a theoretical method that facilitates the application of these philosophical constructs to an examination of legal instruments. This means that discourse analysis can be used to identify the human presuppositions in diverse realms (necessary preconditionalism) to study the web and structure of associations among them (hierarchicalism) and to link them to areas of philosophical reflection. Building on the above considerations, I elaborate on the specificities of using discourse analysis to identify and interlink the philosophical presuppositions of law, which is the ideal object of discourse analysis. ${ }^{40}$

Discourse analysis and philosophical reflection are closely related. Discourse analysis postulates that societies, through language, build a context with at least

\footnotetext{
39 J. Gaarder, Sofies Verden: Roman om filosofiens historie, Aschehoug. Oslo, 2014 (2nd edition); D. Botero Uribe, Vitalismo Cósmico, Siglo del Hombre Editores. Bogotá, 2002; H. Beebee and M. Rush, Philosophy: Why it Matters, Polity. Cambridge, 2019; C. Williams and B. Arrigo, "Philosophy, crime, and theoretical criminology", in B. Arrigo and C. Williams (eds.), Philosophy, Crime and Criminology, University of Illinois Press. Urbana-Champaign, 2006.

$40 \mathrm{~J}$. H. Leung and A. Durant (eds.), Meaning and Power in the Language of Law, Cambridge University Press. Cambridge, 2018.
} 
seven interrelated components that make up their reality. ${ }^{41}$ Of relevance for this study are five of the components, which relate to four branches of philosophy. ${ }^{42}$ First, language constructs a context within which identities exist. A question about the context is in itself philosophical in that it inquires about reality and its actors (ontology)..$^{43}$ Second, language is central in assigning significance to a given issue (axiology). ${ }^{44}$ Third, language contributes to the construction of a hierarchy of knowledge systems (epistemology). ${ }^{45}$ Fourth, language influences the distribution of social goods, "anything people in a society want and value" (political philosophy). ${ }^{46}$

Building on this, a philosophical-legal discourse analysis examines the content of the components present in legal instruments to identify the philosophies underpinning

\footnotetext{
${ }^{41}$ This is but one of many versions of discourse analysis. For other versions, see J. P. Gee and M. Handford (eds.), The Routledge Handbook of Discourse Analysis, Routledge. London, 2014; S. Strauss and P. Feiz, Discourse Analysis: Putting our Worlds into Words, Routledge. London, 2014. 42 To facilitate the identification of components and philosophical branches, I designate the former with italics and the latter with bold in this paragraph.

${ }^{43}$ E. G. Guba and Y. Lincoln, "Competing paradigms in quantitative research", in K. N. Denzin and Y. S. Lincoln (eds.), Handbook of Qualitative Research, Sage. Newbury Park, UK, 1994, p. 108. Specifically about environmental law, we know that most legal instruments regarding nature use a realist/Cartesian logic, which assumes that the environment ("The parts of the world whose current states are not, for the most part, the intended products of human actions". See S. P. James, Environmental Philosophy: An Introduction, Polity. Cambridge, 2015, p. 4.) is value-neutral, which humans can objectively theorise about, and that the task of the human mind is to colonise and civilise the environment through regulations and conceptualisation. See T. D. J. Chappell, "Respecting nature-Environmental thinking in the light of philosophical theory", in T. D. J. Chappell (ed.), The Philosophy of the Environment, Edinburgh University Press. Edinburgh, 1997; A. J. Vetlesen, The Denial of Nature: Environmental Philosophy in the Era of Global Capitalism, Routledge. London, 2016; Vetlesen, Cosmologies... cit.

${ }^{44}$ The study of value judgements through which individuals allocate significance and value to entities, in the fields of morals, aesthetics and economy.

${ }^{45}$ Epistemology considers the nature, or condition, of knowledge, the sources of knowledge, the limits of human knowledge and "the nature of the relationship of the knower or would-be-knower and what can be known". See Guba and Lincoln, "Competing paradigms..." cit., p. 108. Whereas epistemology identifies the diverse sources of knowledge, political dynamics and social constructions mean that some types of knowledge are valued more than others. See E. Krugly-Smolska, "An examination of some difficulties in integrating western science into societies with an Indigenous scientific tradition", in Interchange, num 25, 1994, pp. 325-334; K. Carrington et al., Southern Criminology, Routledge. London, 2019; K. Carrington, R. Hogg and M. Sozzo, "Southern criminology", in British Journal of Criminology, num 56, 2016, pp. 1-20. <doi:10.1093/bjc/azv083>; R. Connell, Southern Theory: The Global Dynamics of Knowledge in Social Science, University of Michigan Press. Ann Arbor, 2007. ${ }^{46}$ J. P. Gee, An Introduction to Discourse Analysis: Theory and Method, Routledge. London, 2014, p. 6. Political philosophy is concerned with studying the distribution of "material goods, and of rights and liberties" as well as the distribution of "political power". See J. Wolff, An Introduction to Political Philosophy, Oxford University Press. Oxford, 2016 (3rd edition), p. 1.
} 
them. In this case, I examine how the language of the Bern Convention and CITES assigns identities and significance and creates a hierarchy of knowledge systems, with the goal of identifying the ontological, axiological and epistemological philosophies informing them. Posteriorly, I discuss how the interlinking of those components results in the distribution of social goods ('anything some people in a society want and value' ${ }^{\prime 4}$ ) between humans, ecosystems and non-human animals. Before moving to the analysis, I provide a brief explanation of how I use the data on which this article is based.

\section{METHODS}

As stated at the outset of this article, the selection of CITES and the Bern Convention as the focus of this study is in response to two considerations. ${ }^{48}$ First, these instruments are binding and central in the regulation of wildlife management in most European countries. Therefore, they are contextually comparable. Second, as Bowman, Davies and Redgwell argue, their axiological bases are in diametrical opposition regarding where they situate the locus of value in nature. ${ }^{49}$ This makes them ideal for the application of the maximum variation principle to find "the full range of extremes" in the phenomena study..$^{50}$ These two reasons combined generate the additional consideration that the conventions are of comparative interest because they are linked by a common conversation about ecological destruction and species extinction. ${ }^{51}$ They are, thus, two of the main voices shaping IWL in Europe, framing how nation-states in the continent manage wildlife.

Analytically, I explored the five components described by discourse analysis that are present in the conventions and related material until I reached a point of concept

\footnotetext{
${ }^{47}$ Gee, An introduction...cit., p. 6.

${ }^{48}$ At first, using them together would seem mistaken considering that the Bern Convention is a regionally driven instrument significantly affected operationally by EU nature conservation law and with a broad focus on ecosystem health, while CITES is a global treaty with a limited mandate.

${ }^{49}$ Bowman et al., Lyster's... cit.

50 K. A. Adams and E. K. Lawrence, Research Methods, Statistics, and Applications, Sage. London, 2019 (2nd edition).

${ }^{51}$ In discourse analysis theory and methodology, the analytical tool of conversation makes possible references to broad social debates on values, beliefs, objects and where there are identifiable positions in the exchange.
} 
saturation. ${ }^{52}$ This amounted to a total of 319 documents: 1) the texts of the two conventions, 2) 100 Resolutions of the Meetings of the Parties to the Convention of CITES (1979-2019), 3) nine Resolutions of the Standing Committee of the Bern Convention (1989-2019) and 4) 208 Recommendations of the Standing Committee of the Bern Convention (1982-2019). In my analysis, I include examples as needed to develop my argument fully, although I could have provided more. One important insight of the analysis is that the underpinning philosophies of both conventions have remained more or less consistent over time.

\section{CONTEXT: INTERNATIONAL ENVIRONMENTAL LAW}

International environmental law contains mandates for states on environmental management, and states are expected to develop and apply corresponding national measures applicable to citizens and corporations. Principle 21 of the Declaration of the United Nations Conference on the Human Environment (1972) (the Stockholm Declaration) is the cornerstone for establishing state sovereignty as the basis of IEL: "States have...the sovereign right to exploit their own resources pursuant to their own environmental policies, and the responsibility to ensure that activities within their jurisdiction or control do not cause damage to the environment of other States or of areas beyond the limits of national jurisdiction". ${ }^{53}$ While such a permanent sovereignty doctrine was incepted already in the 1940s as a "political claim" associated with decolonisation, ${ }^{54}$ the Stockholm Declaration definitively inscribed it as a principle of international law and made of it "a hugely consequential one in the contemporary world", ${ }^{55}$ despite criticisms that it conflicted with the ideals of global justice and lacked a clearly defined normative justification. ${ }^{56}$ In line with this, Dupuy

\footnotetext{
${ }^{52}$ A. Strauss and J. Corbin, "Grounded theory methodology", in N. K. Denzin and Y. S. Lincoln (eds.), Handbook of Qualitative Research, Sage. Newbury Park, UK, 1994.

${ }^{53}$ United Nations, Declaration of the United Nations Conference on the Human Environment, Audio Visual Library of International Law, 1972. <https://legal.un.org/avl/ha/dunche/dunche.html>. [Retrieved on 26 February 2021].

${ }^{54}$ N. Schrijver, Sovereignty over Natural Resources, Cambridge. Cambridge University Press, 2009, p. 1.

55 C. Armstrong, "Against 'permanent sovereignty' over natural resources", Politics, Philosophy \& Economics, num 14, iss 2, p. 130.

${ }^{56}$ Armstrong, "Against 'permanent sovereignty'..." cit.
} 
and Viñuales characterise modern IEL for its use of the principle of permanent sovereignty over natural resources as the "building block of modern environmental regulation". ${ }^{57}$ As further traits of IEL, they also point out its focus on "protecting the environment per se (essentially for human purposes but not only as a useful resource)" and the "sophistication of the legal techniques developed to this effect". ${ }^{58}$ Bodansky, Brunnee and Rajamani add another dimension to Dupuy and Viñuales's characterisation in their claim that modern IEL was designed mainly to resolve conflicts related to the sovereignty of a state. ${ }^{59}$

\section{International Treaties on Wildlife Species, Ecosystems and Biodiversity}

The protection of wildlife is one of the primary concerns of IEL, and treaties are an important instrument to this end. They are the written agreements of two or more states, regulated by international law. The manifest function of treaties in IEL is to achieve a reciprocal adjustment of interests by the states, while respecting their sovereignty and using the formal equality principle in their interactions. In practice, however, international environmental treaties are characterized by asymmetrical obligations to the parties, which means that they are not dependant on reciprocity but are based primarily on geopolitical divisions. As in IEL, the goal of IWL treaties has shifted from protecting wildlife as a resource, to a combination of safeguarding economic interests while simultaneously conserving wildlife for its ecological and aesthetic value.

While "the number and diversity of international instruments for the protection of animal and plant life makes any attempt to capture the major axes of this area of regulation a challenging exercise",60 CITES and the Bern Convention are undoubtedly among the most important treaties for the protection of species, ecosystems and biodiversity in Europe. CITES (1973) came into existence because

\footnotetext{
57 P.-M. Dupuy and J. Viñuales, International Environmental Law, Cambridge University Press. Cambridge, 2019, pp. 3, 7.

${ }^{58}$ Dupuy and Viñuales, International Environmental Law... cit., p. 3.

59 D. Bodansky, J., Brunnee and L. Rajamani, International Climate Change Law, Oxford University Press. Oxford, 2017.

60 Dupuy and Viñuales, International Environmental Law... cit., p. 202.
} 
of the efforts begun in the 1960s of various organisations, mainly the International Union for Conservation of Nature, to urge governments to take action to prevent illegal wildlife trade. ${ }^{61}$ The original goal was "to set up a system through which the trade controls in importing countries could be matched with those in the exporting countries", as a way to advance conservation. ${ }^{62}$ The overarching goal of CITES is to "save wild species from extinction" by regulating wildlife trade, ${ }^{63}$ and it commits to sustainability in order to maintain trade. ${ }^{64}$ Its main mechanisms are "regulation and restriction of the international trade in wildlife". ${ }^{65}$ CITES uses a system of three lists of endangered species: "Appendix I lists species that are the most endangered among CITES-listed animals and plants....They are threatened with extinction and CITES prohibits international trade in specimens of these species except when the purpose of the import is not commercial". Appendix II "lists species that are not necessarily now threatened with extinction but that may become so unless trade is closely controlled". Appendix III "is a list of species included at the request of a Party that already regulates trade in the species and that needs the cooperation of other countries to prevent unsustainable or illegal exploitation". 66

The Bern Convention (1979) originated in "a request made by the Parliamentary Assembly of the Council of Europe in 1973 requesting European regulations for the protection of wildlife". ${ }^{67}$ Its purpose is to protect European wild plants and animalsparticularly those endangered —and their habitats, as well as advancing cooperation

61 C. Huxley, "CITES: The vision", in J. Hutton and B. Dickson (eds.), Endangered Species Threatened Convention: The Past, Present and Future of CITES, Routledge. London, 2000.

62 Huxley, "CITES..." cit., p. 11. A decade after the implementation of CITES, various NGOs began discussing issues of animal rights and animal welfare. This initiated a conflict between NGOs and the initial proponents of the convention. The latter responded with concerns that NGO intervention would "derail or divert the convention from its original direction". See Huxley, "CITES..." cit., p. 10. Nevertheless, CITES still conserves a spirit of trade regulation and currently has 184 parties to the convention.

${ }^{63}$ Hutton and Dickson, "Introduction..." cit., p. xv.

64 Sollund, The Crimes... cit.

65 Hutton \& Dickson, "Introduction..." cit., p. xv.

${ }^{66}$ CITES, The CITES appendices, n. d. <https://www.cites.org/eng/app/index.php>. [Retrieved on 26 February 2021].

${ }^{67}$ C. L. Diaz, "The Bern Convention: 30 years of nature conservation in Europe" in RECIEL, num 19, 2010, p. 186. See, also, S. Jen, "The Convention on the Conservation of European Wildlife and Natural Habitats (Bern, 1979): Procedures of application in practice", in Journal of International Wildlife and Law Policy, num 2, 1999. 
among countries to this end. One of the obligations that the Bern Convention imposes on states is to take suitable administrative and legal measures to maintain adequate population levels of species to secure their survival. ${ }^{68}$ The Bern Convention also functions as a basis for "ample collaboration between the countries", for instance, through collective decisions that express the "common view" of the partners, and through the Emerald Network that creates natural protection areas in Europe. ${ }^{69}$ This convention also works with a system of lists: Appendix I lists "strictly protected flora species", Appendix II includes "strictly protected fauna species", Appendix III registers "protected fauna species" and Appendix IV records "prohibited means and methods of killing, capture and other forms of exploitation". ${ }^{70}$

\section{FINDINGS: TWO INTERACTING CONVENTIONS AT ODDS}

In the following sections I pay attention to how the language of CITES and the Bern Convention construct views related to ontology, axiology and epistemology. The overarching finding is that they are in contention in all three realms.

\section{Ontology: Individual State Sovereignty Versus Regional Cooperation}

The Bern Convention and CITES create identities for their parties and for the subjects to which they refer. CITES does so directly: "the peoples and States are and should be the best protectors of their own wild fauna and flora"71 and "the provisions of the present Convention shall in no way affect the provisions of any domestic measures or the obligations of Parties deriving from any treaty, convention, or international agreement relating to other aspects of trade, taking, possession or transport of specimens". ${ }^{72}$ In these excerpts, CITES highlights the role of individual

\footnotetext{
${ }^{68}$ Council of Europe, Convention... cit., Article 2.

${ }^{69}$ H. C. Bugge, Lærebok i miljøforvaltingsrett, Universitetsforlaget. Oslo, 2019, p. 297.

${ }^{70}$ See Council of Europe, Details of Treaty No. 104, n. d. $<$ https://www.coe.int/en/web/conventions/full-list/-/conventions/treaty/104>. [Retrieved on 26 February 2021].

${ }^{71}$ CITES, Convention text... cit., preamble. See, also, CITES, Resolution of the fifteenth meeting of the Conference of the Parties, Wildlife trade policy reviews (Conf. 15.2), 2010. $<$ https://cites.org/sites/default/files/document/E-Res-15-02.pdf>. [Retrieved on 26 February 2021].

${ }^{72}$ CITES, Convention text... cit., Article XIV.2.
} 
states in managing their wildlife and stressing their right not to have their sovereignty infringed upon. Sovereignty, with its components of territorial management and nointrusion, permeates the resolutions of the Conference of the Parties to the Convention (CoP), issued every two to three years. Most CoP resolutions allocate exclusive responsibility to nation-states to control trade in wildlife within their territories. For instance, during the eleventh CoP, all parties were urged "to strengthen, as soon as possible, the controls on trade in wildlife in the territories under their jurisdiction". ${ }^{73}$ With this emphasis, the primary aspect of the identity of nations is their sovereignty and, consequently, nature is seen as nationally owned.

In contrast, the Council of Europe builds strong cooperative relationships among its members through the resolutions and recommendations of the Bern Convention. Its preamble establishes the need to "achieve a greater unity between its members" and the need for nation-states "to co-operate with other States in the field of nature conservation". ${ }^{74}$ Article 1 makes clear the intention of the convention to foster cooperative conservation: nation-states "are to conserve wild flora and fauna and their natural habitats... whose conservation requires the co-operation of several States, and to promote such co-operation". ${ }^{75}$ Articles 9.2, 10 and 11 and several of the resolutions of the SC also promote cooperation. For instance, Resolution 2 (1993) reinforces interdependence by mandating that "in a case of a transboundary population", parties must consider "its entire habitat and subpopulations" as well as "cumulative effects". ${ }^{76}$ The desire for strong European collaborative relationships is expressed most clearly in Resolution 3 of the SC (1996), which states that the governing body of the Bern Convention is "desirous" to "contribute as a first step to the implementation of the Pan-European Biological and Landscape Diversity Strategy". ${ }^{77}$

\footnotetext{
${ }^{73}$ CITES, Resolution of the eleventh meeting of the Conference of the Parties, Compliance and enforcement (Conf. 11.3 [Rev. CoP18]), 2019. <https://cites.org/sites/default/files/document/E-Res11-03-R18.pdf>. [Retrieved on 26 February 2021].

${ }^{74}$ Council of Europe, Convention... cit., preamble.

${ }^{75}$ Council of Europe, Convention... cit., Article 1.

${ }^{76}$ Council of Europe, Resolutions of the Standing Committee, Resolution 2, 1993, p. 3.

${ }^{77}$ Council of Europe, Resolutions of the Standing Committee, Resolution 3, 1996, p. 1.
} 


\section{Axiology: Species and Trade Vis-à-vis Ecosystems and Subsistence}

While the building tasks of "significance" and "connections" are usually separated in discourse analysis, they are in actuality intricately connected. As axiological premises show, the significance of something depends on the allocation of value to its diverse entities. That comparison can emerge only from drawing connections. In this arena, CITES establishes the "aesthetic, scientific, cultural, recreational and economic" value of wildlife. The significance of wildlife is derived from its "beautiful and varied forms", and CITES seeks to protect it "for this and the generations to come". ${ }^{78}$ CITES's focus relies on the survival of species as the carriers of unique genetic information. ${ }^{79}$ Nevertheless, CITES, in its CoP resolutions, also presents commerce as a necessary evil that must be respected to protect species. This is unsurprising considering that CITES is a trade agreement. In Resolution 8.3 (1992), the parties declared that "commercial trade may be beneficial to the conservation of ecosystems or to the development of local people...[and] the implementation of CITES-listing decisions should take into account potential impacts on the livelihoods of the poor" ${ }^{80} \mathrm{~A}$ milestone in the axiological positioning of CITES was the adoption of the Addis Ababa principles and guidelines by the parties, along with a commitment to sustainable development. The Addis Ababa principles call for the removal of economically detrimental laws and regulations (practical principle 3 ) and for taking into account "current and potential values derived from the use of biological diversity" and "market forces affecting the values and use [of biological diversity]" (practical principle 10). ${ }^{81}$ The formulation of CITES's Strategic Vision: 2008-2020 (2013) reinforced the focus on and engagement in sustainable development: the vision statement declares that CITES seeks to "conserve biodiversity and contribute to its

\footnotetext{
${ }^{78}$ CITES, Convention text... cit., preamble.

${ }^{79}$ Bowman et al., Lyster's... cit.

${ }^{80} \mathrm{CITES}$, Resolution of the eighth meeting of the Conference of the Parties, Recognition of the benefits of trade in wildlife (Conf. 8.3 [Rev. CoP13]), 1992. <https://cites.org/sites/default/files/document/E-Res-08-03-R13.pdf>. [Retrieved on 26 February 2021].

81 Secretariat of the Convention on Biological Diversity, "Addis Ababa principles and guidelines for the sustainable use of bodiversity", Practical principles 3 and 10, 2004. $<$ https://www.cbd.int/doc/publications/addis-gdl-en.pdf>. [Retrieved on 26 February 2021].
} 
sustainable use by ensuring that no species of wild fauna or flora becomes or remains subject to unsustainable exploitation through international trade" ${ }^{82}$

The Bern Convention explicitly establishes in its preamble (and repeats in Article 2) the "aesthetic, scientific, cultural, recreational, economic and intrinsic value" and consideration of "future generations" as the criteria for the valuing of wild flora and fauna. In addition, it emphasizes "the essential role played by wild flora and fauna in maintaining biological balances". Its preamble also draws attention to the fact that "numerous species of wild flora and fauna are being seriously depleted" and calls for "particular emphasis" on "endangered and vulnerable species". ${ }^{83}$ These declarations indicate ecological justice as fundamental for axiological considerations. Ecological justice is concerned with the integrity of ecosystems in a holistic manner and sees ecosystems as intrinsically valuable in such a way that the totality of the ecosystem is more important than the sum of its parts. ${ }^{84}$ The Bern Convention, nevertheless, in Article 9 allows exceptions to the mandates of the convention regarding the protection of wild animals "to prevent serious damage to crops, livestock, forest, fisheries, water and other forms of property" 85 "in the interests of public health and safety" and "for the purposes of research and education". It also allows for "judicious exploitation of certain wild animals and plants in small number" in the case of people making a subsistence livelihood. ${ }^{86}$

\section{Epistemology: Quantitative Science Versus Instrumental Diplomacy}

CITES relies on scientific knowledge in the form of quantitative data, which it implicitly portrays as superior to other forms of natural management knowledge, such as Indigenous knowledge. It was only in 2019 , during the $18^{\text {th }} \mathrm{CoP}$, when the Standing Committee decided to "consider how to effectively engage indigenous

\footnotetext{
${ }^{82}$ CITES, Conf.16. \#3.

${ }^{83}$ Council of Europe, Convention... cit., preamble.

${ }^{84}$ R. White (ed.), Environmental Crime: A Reader, Willian. Collumpton, UK, 2009.

${ }^{85}$ Council of Europe, Resolution 2... cit., p. 3. The resolution also states: "'serious' [damage] does not, of course, necessarily mean that the damage was widespread" and that "it is not required that the damage be already present. Rather, it is sufficient if serious damage in all likelihood will occur".

${ }^{86}$ Council of Europe, Resolution 2... cit.
} 
peoples and local communities in the CITES processes" ${ }^{87}$. Nevertheless, this decision remains to be implemented. Meanwhile, the priority of scientific language is established with definitions such as "[s]pecies means any species, subspecies, or geographically separate population thereof". ${ }^{88}$ But it is developed most explicitly in the CoP resolutions. For example, the resolution of the tenth CoP states that "the finding and advice of the Scientific Authority of the country of export [should] be based on the scientific review of available information on the population status, distribution, population, trend, harvest and other biological and ecological factors". ${ }^{89}$ Scientific language permeates the latest resolution of the CoP (2019): "Parties' decisions are [to be] supported by the best available science and information". ${ }^{90}$ In all of this, CITES makes determinations based on a quantitative understanding of wildlife trade and does not take into account other valid knowledge, such as lay or traditional knowledge, about the topic.

While the Bern Convention places the determination of the size of wildlife populations as dependent on "ecological, scientific and cultural requirements", ${ }^{91}$ and while it can be assumed that it embraces scientific language, it is written in diplomatic social language. Most of the recommendations use soft language such as "avoid", "consider", "encourage", "favour", "reassess" and "promote". This can be explained in part by the fact that every resolution of the SC is non-binding unless every party agrees to add it as an amendment to the main treaty. Consequently, the SC cannot

${ }^{87}$ CITES, Resolution of the eighteenth meeting of the Conferences of the Parties, Engagement of indigenous peoples and local communities (Conf 18.31), 2018, <https://cites.org/eng/node/55648>. [Retrieved on 13 June 2021]

${ }^{88}$ CITES, Convention text... cit., Article I(a).

${ }^{89}$ CITES, Resolution of the tenth meeting of the Conference of the Parties, Designation and role of the scientific authorities (Conf. 10.3), 1997, \#2. <https://cites.org/sites/default/files/document/E-Res10-03_0.pdf>. [Retrieved on 26 February 2021]. See, also, CITES, Resolution of the third meeting of the Conference of the Parties, Technical cooperation (Conf. 3.4), 1981. $<$ https://cites.org/sites/default/files/document/E-Res-03-04.pdf>. [Retrieved on 26 February 2021]; CITES, Resolution of the fifth meeting of the Conference of the Parties, Guidelines for the Secretariat when making recommendations in accordance with Article XV (Conf. 5.20 [Rev. CoP17]), 1985. $<$ https://cites.org/sites/default/files/document/E-Res-05-20-R17.pdf>. [Retrieved on 26 February 2021].

${ }^{90}$ CITES, Resolution of the eleventh meeting... cit.; CITES, Resolution of the eighteenth meeting of the Conference of the Parties, CITES strategic vision, 2021-2030 (Conf. 18.3), 2019, \#5. $<$ https://cites.org/sites/default/files/document/E-Res-18-03_0.pdf>. [Retrieved on 26 February 2021].

${ }^{91}$ Council of Europe, Convention... cit., Article 2. 
require any party to adhere to the resolutions. An example is Recommendation 8 (1987), in which the SC "recommends that the Government of Turkey...consider the protection of the Dalyan area as a national park or a biogenetic reserve in order to ensure the protection of sea turtles". ${ }^{92}$ Another example is the SC's recommendation that "appropriate legal and administrative measures, the promotion of education of hunters and the general public and the dissemination of information" regarding the illegal catching, killing and trading of protected birds be undertaken. ${ }^{93}$ The result of this social language is that it offers a soft, suggestive approach instead of establishing clear guidelines. Even in cases when the SC acknowledges that specific animals are threatened, it uses weak diplomatic language, like recommending that parties "give special conservation attention to all small populations of mammal species which are endangered or vulnerable...evaluate whether the species or populations...require recovery plans [and]...if appropriate or relevant, design conservation and recovery plans". ${ }^{94}$

\section{DISCUSSION AND CONCLUSION: FUNDAMENTAL CONTRADICTIONS, POLITICAL PHILOSOPHY AND FUTURE CHALLENGES}

Studies critical of the Bern Convention and CITES have noted that the conventions were aligned in allowing for the use of wildlife for profit-making as an axiological fundament. With such an axiological basis, the distribution of social goods takes on an econocentric significance concerned with economic health at the expense of environmental and human health, wellbeing and protection. ${ }^{95}$ Furthermore, the present study has also shown that they share an epistemological reliance on quantitative science and on instrumental political knowledge, which points towards a decision-making monopoly on wildlife matters. These knowledge systems are

\footnotetext{
${ }^{92}$ Council of Europe, Recommendation 8 of the Standing Committee, 1987. Italics mine.

${ }^{93}$ Council of Europe, Recommendation 5 of the Standing Committee, 1986. Italics mine.

${ }^{94}$ Council of Europe, Recommendation 43 of the Standing Committee, 1995.

95 Brisman and South, "Autosarcophagy..." cit. See, also, D. R. Goyes and N. South, "Between 'conservation' and 'development': The construction of 'protected nature' and the environmental disenfranchisement of Indigenous communities", in International Journal for Crime, Justice and Social Democracy, num 89, 2019, pp. 89-104. A. Brisman et al., Water, Crime and Security in the TwentyFirst Century, London, Palgrave, 2018.
} 
mechanisms used to impose social organisation: they allocate exclusive power to some actors to regulate behaviour in relation to wildlife, while denying the possibility for more open, democratic and argument-based ruling. For instance, scientific quantitative language is a "monopolised" social language because it "silences" everyone beyond the inner circle. ${ }^{96}$ This produces a context in which very few actors are able to participate in determining the distribution of social goods, such as respect for one's life and habitat, in the arena of wildlife management.

Despite those similarities, the main finding of this article is that the Bern Convention and CITES have various contending philosophical pillars (see table 1). A possible hypothesis of the consequences of the disparity in the philosophical bases of these conventions, which engage in the same conversation and are applicable in the same arenas, is that it might result in their derived wildlife public policies counteracting each other. Here, and elsewhere, ${ }^{97}$ following the work of Frank Fischer, I understand public policy as "a coordinated action plan established by an official authority, in which resources are assigned". ${ }^{98}$ Following this definition, if national wildlife plans encouraged by CITES and the Bern Convention are indeed policies, that is, highly coordinated and coherent, they would have to a) be focused either on a national or a pan-European identity, b) prioritise either species or ecosystems as a whole or c) be either reliant on objective scientific knowledge or based on diplomatic considerations. This dichotomous hypothesis is, nevertheless, refuted by studies that show that wildlife plans are politically contingent rather than philosophically stable. ${ }^{99}$

\footnotetext{
${ }^{96}$ N. Christie, Små ord for store spørsmål [Small words for big questions], Universitetsforlaget. Oslo, 2009; South, "The contested planet..." cit.

${ }_{97}$ D. R, Goyes, "La necesidad de una política preventiva verde en Colombia" [The need of a green preventive public policy in Colombia], in Política Criminal y Prevención, M. Gutiérrez Quevedo (ed.), Universidad Externado de Colombia. Bogotá, 2015, p. 146.

98 F. Fischer, Reframing Public Policy, Discursive Politics and Deliberative Practices, New York. Oxford University Press, 2003, p. 266. Italics mine.

${ }^{99}$ See for instance, the outcomes of the project "Criminal justice, wildlife conservation and animal rights in the Anthropocene-CRIMEANTHROP", which is analysing CITES and the Bern Convention jointly, demonstrating that their application in Norway follows disparate, independent lines. For more details about the project, see Acknowledgments.
} 
Table 1. Philosophical bases of CITES and the Bern Convention

\begin{tabular}{|l|l|l|l|}
\hline \multicolumn{1}{|c|}{$\begin{array}{c}\text { Discourse } \\
\text { analysis } \\
\text { component }\end{array}$} & \multicolumn{1}{|c|}{$\begin{array}{c}\text { Philosophical } \\
\text { realm }\end{array}$} & \multicolumn{1}{|c|}{ CITES } & Bern Convention \\
\hline $\begin{array}{l}\text { Context and } \\
\text { identity }\end{array}$ & Ontology & $\begin{array}{l}\text { Environmental } \\
\text { nationalism }\end{array}$ & $\begin{array}{l}\text { Environmental } \\
\text { regionalism }\end{array}$ \\
\hline $\begin{array}{l}\text { Significance and } \\
\text { connections }\end{array}$ & Axiology & $\begin{array}{l}\text { - Values species } \\
\text { conservation } \\
\text { - Values trade }\end{array}$ & $\begin{array}{l}\text { - Values } \\
\text { ecosystem } \\
\text { conservation } \\
\text { - Values } \\
\text { subsistence }\end{array}$ \\
\hline $\begin{array}{l}\text { Social languages } \\
\text { and knowledge } \\
\text { systems }\end{array}$ & Epistemology & $\begin{array}{l}\text { Privileges } \\
\text { "objective" } \\
\text { positivist } \\
\text { knowledge }\end{array}$ & $\begin{array}{l}\text { Privileges } \\
\text { politically } \\
\text { instrumental } \\
\text { knowledge }\end{array}$ \\
\hline
\end{tabular}

A second, more likely, hypothesis is that the ambivalence of IWL instruments involved in the same conversation and with the same territoriality, such as CITES and the Bern Convention, produce such a high level of discretional power that nationstates stop being bounded by the substratum of the conventions and can limit themselves to following the technicalities and procedures mandated by the instruments. Additionally, the phenomenon is strengthened by the permanent sovereignty doctrine (see above) that reasserts states' almost absolute dominion over its environmental jurisdiction. The philosophical ambivalence of IWL instruments, which allows states an array of acceptable philosophical pillars, when combined with the permanent sovereignty doctrine, which strengthens the state's decisional freedom, removes from the conventions the ambitious commitment that inspired them (see Context section) and mainly leaves a formalistic shell. Consequently, the philosophical ambivalence of CITES and the Bern Convention goes a long way to explain their suboptimal performance: while commentators expect that they offer real protection to wildlife, they fall prey to "legal fetishism", which is defined as the belief that "law can change reality" about itself. Thus, 
"focusing on the rituals of the law, rather than on its efficacy", 100 they implicitly open the possibility for various politically contingent wildlife management plans.

One of the future challenges for legal wildlife scholars is to explore in detail the legislative processes through which nations incorporate international commitments into state law, and to evaluate how the contentious messages they receive play out. Additionally, the insights of this discussion suggest that, to increase the efficiency of IEL and IWL by reducing states' volition, the message its instruments send out should be philosophically univocal.

\section{Acknowledgements}

This study was produced as part of the project "Criminal justice, wildlife conservation and animal rights in the Anthropocene-CRIMEANTHROP" in the Department of Criminology and Sociology of Law, University of Oslo. It is funded by the Granting Committee for the Humanities and Social Sciences (FRIPRO) of the Research Council of Norway, project number 289285. I thank Avi Brisman, Teresa Fajardo, Ragnhild Sollund and Nigel South for their comments on previous versions of this article. Likewise, this text has benefited from three rounds of peer reviews. I appreciate the time and dedication of those reviewers to securing the quality of academic production.

\section{References}

Adams, K. A. and Lawrence, E. K., Research Methods, Statistics, and Applications, Sage. London, 2019 (2nd edition).

Armstrong, C., "Against 'permanent sovereignty' over natural resources", in Politics, Philosophy \& Economics, num 14, iss 2, 2015.

\footnotetext{
100 J. Lemaitre Ripoll, "Legal fetishism: Law, violence, and social movements in Colombia", In Revista Jurídica de la Universidad de Puerto Rico, num 77, iss 2, 2008, pp. 331-344.
} 
Baker, J. E., "A substantive theory of the relative efficiency of environmental treaty compliance strategies: The case of CITES", in Journal of International Wildlife Law and Policy, num 2, 1999. <doi:10.1080/13880299909353918>.

Bar-On, Y. M., Phillips, R. and Milo, R., "The biomass distribution on earth", in Proceedings of the National Academy of Sciences, num 115, iss 25, 2018. $<$ doi:10.1073/pnas.1711842115>.

Barrow, C. J. and Matthews, J. A., "Environmental philosophy", in J. A. Matthews (ed.), Encyclopedia of Environmental Change, 2014. $<$ doi.org/10.4135/9781446247501.n1314>.

Bauer, H., Nowell, K., Sillero-Zubiri, C. and Macdonald, D. W., "Lions in the modern arena of CITES", in Conservation Letters, num 11, 2018. $<$ doi.org/10.1111/conl.12444>.

Beebee, H. and Rush, M., Philosophy: Why it Matters, Polity. Cambridge, 2019.

Bodansky, D., Brunnee, J. and Rajamani, L., International Climate Change Law, Oxford University Press. Oxford, 2017.

Booth, W.C., et al., The Craft of Research, Chicago: University of Chicago Press, 2016.

Botero Uribe, D., Vitalismo Cósmico, Siglo del Hombre Editores. Bogotá, 2002.

Bowman, M., "Conflict or compatibility? The trade, conservation and animal welfare dimensions of CITES", in Journal of International Wildlife Law and Policy, num 1, iss 1, 1998. <doi:10.1080/13880299809353883>.

Bowman, M., Davies, P. and Redgwell, C., Lyster's International Wildlife Law, Cambridge University Press. Cambridge, 2010.

Brisman, A., et al., Water, Crime and Security in the Twenty-First Century, London. Palgrave, 2018.

Brisman, A. and South, N., "Autosarcophagy in the Anthropocene and the obscenity of an epoch", in C. Holley and C. Shearing (eds.), Criminology and the Anthropocene, Routledge. London, 2018.

Bugge, H. C., Lærebok i miljøforvaltingsrett [Environmental law textbook], Universitetsforlaget. Oslo, 2019. 
Carrington, K., Hogg, R., Scott, J., Sozzo, M. and Walters, R., Southern Criminology, Routledge. London, 2019.

Carrington, K., Hogg, R. and Sozzo, M., "Southern criminology", in British Journal of Criminology, num 56, 2016. <doi:10.1093/bjc/azv083>.

Chappell, T. D. J., "Respecting nature-Environmental thinking in the light of philosophical theory", in T. D. J. Chappell (ed.), The Philosophy of the Environment, Edinburgh University Press. Edinburgh, 1997.

Christie, N., Små ord for store spørsmål [Small words for big questions], Universitetsforlaget. Oslo, 2009.

CITES, The CITES appendices, n.d. <https://www.cites.org/eng/app/index.php>. [Retrieved on 26 February 2021].

CITES, Convention text, 1983. <https://cites.org/eng/disc/text.php\#texttop>. [Retrieved on 26 February 2021].

CITES, Resolution of the eighteenth meeting of the Conference of the Parties, CITES strategic vision, 2021-2030 (Conf. 18.3), 2019. <https://cites.org/sites/default/files/document/E-Res-18-03_0.pdf>.

[Retrieved on 26 February 2021].

CITES, Resolution of the eighth meeting of the Conference of the Parties, Recognition of the benefits of trade in wildlife (Conf. 8.3 [Rev. CoP13]), 1992. $<$ https://cites.org/sites/default/files/document/E-Res-08-03-R13.pdf>.

[Retrieved on 26 February 2021].

CITES, Resolution of the eleventh meeting of the Conference of the Parties, Compliance and enforcement (Conf. 11.3 [Rev. CoP18]), 2019. $<$ https://cites.org/sites/default/files/document/E-Res-11-03-R18.pdf>. [Retrieved on 26 February 2021].

CITES, Resolution of the fifteenth meeting of the Conference of the Parties, Wildlife trade policy reviews (Conf. 15.2), 2010. $<$ https://cites.org/sites/default/files/document/E-Res-15-02.pdf>. [Retrieved on 26 February 2021].

CITES, Resolution of the fifth meeting of the Conference of the Parties, Guidelines for the Secretariat when making recommendations in accordance with Article 
$\begin{array}{lllll}X V & \text { (Conf. } & 5.20 & \text { [Rev. } & \text { CoP17]), }\end{array}$ $<$ https://cites.org/sites/default/files/document/E-Res-05-20-R17.pdf>. [Retrieved on 26 February 2021].

CITES, Resolution of the tenth meeting of the Conference of the Parties, Designation and role of the scientific authorities (Conf. 10.3), 1997, \#2. <https://cites.org/sites/default/files/document/E-Res-10-03_0.pdf>. [Retrieved on 26 February 2021].

CITES, Resolution of the third meeting of the Conference of the Parties, Technical $\begin{array}{llll}\text { cooperation } & \text { (Conf. } & 3.4 \text { ), }\end{array}$ $<$ https://cites.org/sites/default/files/document/E-Res-03-04.pdf>. [Retrieved on 26 February 2021].

Connell, R., Southern Theory: The Global Dynamics of Knowledge in Social Science, University of Michigan Press. Ann Arbor, 2007.

Council of Europe, Convention on the conservation of European wildlife and natural habitats, 1979. <https://www.cbd.int/doc/publications/addis-gdl-en.pdf>. [Retrieved on 26 February 2021].

Council of Europe, Details of Treaty No. 104, n. d. <https://www.coe.int/en/web/conventions/full-list/-/conventions/treaty/104>. [Retrieved on 26 February 2021].

Council of Europe, Recommendation 5 of the Standing Committee, 1986.

Council of Europe, Recommendation 8 of the Standing Committee, 1987.

Council of Europe, Recommendation 43 of the Standing Committee, 1995.

Council of Europe, Resolutions of the Standing Committee, Resolution 2, 1993.

Council of Europe, Resolutions of the Standing Committee, Resolution 3, 1996.

Crutzen, P. J., "The 'Anthropocene'”, in E. Ehlers and T. Krafft (eds.), Earth System Science in the Anthropocene, Springer. New York, 2006.

Diaz, C. L., "The Bern Convention: 30 years of nature conservation in Europe", in RECIEL, num 19, 2010.

Dupuy, P.-M. and Viñuales, J., International Environmental Law, Cambridge University Press. Cambridge, 2019. 
Epstein, Y., "The habitats directive and Bern Convention: Synergy and dysfunction in public international and EU law", in Georgetown Environmental Law Review, num 26, 2014.

"Failures of Environmental Protection", Georgetown Environmental Law Review, num 16, 2004.

Fischer, F., Reframing Public Policy, Discursive Politics and Deliberative Practices, New York. Oxford University Press, 2003.

Gaarder, J., Sofies Verde: Roman om filosofiens historie, Aschehoug. Oslo, 2014 (2nd edition).

Gee, J. P., An Introduction to Discourse Analyis: Theory and Method, Routledge. London, 2014.

Gee, J. P. and Handford, M. (eds.), The Routledge Handbook of Discourse Analysis, Routledge. London, 2014.

Gillespie, A., International Environmental Law, Policy, and Ethics, Oxford University Press. Oxford, 2014 (2nd edition).

Goyes, D. R., "La necesidad de una política preventiva verde en Colombia", in Política Criminal y Prevención, M. Gutiérrez Quevedo (ed.), Universidad Externado de Colombia. Bogotá, 2015.

Goyes, D. R. and Sollund, R., "Contesting and contextualising CITES: Wildlife trafficking in Colombia and Brazil", in International Journal for Crime, Justice and Social Democracy, num 5, 2016.

Goyes, D. R. and South, N., "Between 'conservation' and 'development': The construction of 'protected nature' and the environmental disenfranchisement of Indigenous communities", in International Journal for Crime, Justice and Social Democracy, num 8, 2019.

Graham, K., "International intent and domestic application of the Convention on International Trade in Endangered Species of Wild Fauna and Flora (CITES): The case of the ocelot (Leopardus pardalis)", in Journal of International Wildlife Law and Policy, num 20, 2017. $<$ doi:10.1080/13880292.2017.1403797>. 
Grooten, M. and Almond, R. E. A., Living Planet Report: Aiming Higher, World Wildlife Federation, 2018. $<$ https://wwf.panda.org/knowledge_hub/all_publications/living_planet_report _2018/>. [Retrieved on 26 February 2021].

Guba, E. G. and Lincoln, Y., "Competing paradigms in quantitative research", in K. N. Denzin and Y. S. Lincoln (eds.), Handbook of Qualitative Research, Sage. Thousand Oaks, CA, 1994.

Harrop, S. and Bowles, D., "Wildlife management, the multilateral trade regime, morals and the welfare of animals", in Journal of International Wildlife Law and Policy, num 1, 1998. <doi:10.1080/13880299809353884>.

Heinen, J. T. and Chapagain, D. P., "On the expansion of species protection in Nepal: Advances and pitfalls of new efforts to implement and comply with CITES", in Journal of International Wildlife Law and Policy, num 5, 2022. $<$ doi:10.1080/13880290209354012>.

Hutton, J. and Dickson, B., "Introduction", in. J. Hutton and B. Dickson (eds.), Endangered Species Threatened Convention: The Past, Present and Future of CITES, Routledge. London, 2000.

Huxley, C., "CITES: The vision", in J. Hutton and B. Dickson (eds.), Endangered Species Threatened Convention: The Past, Present and Future of CITES, Routledge. London, 2000.

James, S. P., Environmental Philosophy: An Introduction, Polity. Cambridge, 2015. Jen, S., "The Convention on the Conservation of European Wildlife and Natural Habitats (Bern, 1979): Procedures of application in practice", in Journal of International Wildlife and Law Policy, num 2, 1999.

Korwin, S., Denier, L., Lieberman, S. and Reeve, R., "Verification of legal acquisition under the CITES convention: The need for guidance on the scope of legality", in Journal of International Wildlife Law and Policy, num 22, 2019. <doi:10.1080/13880292.2019.1695718>.

Kothari, A. and Anuradha, R. V., "Biodiversity and intellectual property rights: Can the two co-exist?" in Journal of International Wildlife Law and Policy, num 2, 1999. <doi:10.1080/13880299909353928>. 
Krugly-Smolska, E., "An examination of some difficulties in integrating western science into societies with an Indigenous scientific tradition", in Interchange, num 25, 1994.

Le, T. "CITES as global governance: Paths to consensus and defining nature through uncertainty", in Journal of International Wildlife Law and Policy, num 22, 2019. <doi:10.1080/13880292.2019.1629176>.

Lemaitre Ripoll, J., "Legal fetishism: Law, violence, and social movements in Colombia", in Revista Jurídica de la Universidad de Puerto Rico, num 77, iss 2, 2008.

Leung, J. H. and Durant, A. (eds.), Meaning and Power in the Language of Law, Cambridge University Press. Cambridge, 2018.

Lewis, M. G., "CITES and rural livelihoods: The role of CITES in making wildlife conservation and poverty reduction mutually supportive", in Journal of International Wildlife Law and Policy, num 12, 2009. <doi:10.1080/13880290903433014>.

Lynch, M. J., Long, M. A., Barret, K. L. and Stretesky, P. B., "Is it a crime to produce ecological disorganization?" in British Journal of Criminology, num 53, 2013, pp. 997-1016. <doi:10.1093/bjc/azt051>.

Maunder, M., Higgens, S. and Culham, A., "The effectiveness of botanic garden collections in supporting plant conservation: A European case study", in Biodiversity and Conservation, num 10, iss 3, 2001.

Persaud, S., "Losing our 'CITES' on the 'traffic': How taxing ivory trafficking can save the African elephant from its bloody extinction", in Journal of International Wildlife Law and Policy, num 20, 2017. <doi:10.1080/13880292.2017.1403813>.

Sazatornil, V., Trouwborst, A., Chapron, G., Rodríguez, A. and López-Bao, J. V., "Top-down dilution of conservation commitments in Europe: An example using breeding site protection for wolves", in Biological Conservation, num 237, 2019. <doi.org/10.1016/j.biocon.2019.06.027>.

Schrijver, N., Sovereignty over Natural Resources, Cambridge. Cambridge University Press, 2009. 
Secretariat of the Convention on Biological Diversity, "Addis Ababa principles and guidelines for the sustainable use of biodiversity", 2004. $<$ https://www.cbd.int/doc/publications/addis-gdl-en.pdf>. [Retrieved on 26 February 2021].

Sollund, R., "Animal trafficking and trade: Abuse and species injustice", in R. Walters, D. Westerhuis and T. Wyatt (eds.), Emerging Issues in Green Criminology, Palgrave Macmillan. London, 2013.

Sollund, R., The Crimes of Wildlife Trafficking: Issues of Justice, Legality and Morality, Routledge. London, 2019.

Sollund, R., "Expressions of speciesism: The effects of keeping companion animals on animal abuse, animal trafficking and species decline", in Crime, Law and Social Change, num 55, 2011. <doi:10.1007/s10611-011-9296-3>.

Sollund, R., "Wildlife management, species injustice and ecocide in the Anthropocene", in Critical Criminology, num 28, iss 25, 2019. <doi:10.1007/s10612-019-09469-1>.

Sollund, R., Larsen, G. and Tønnesen, M. (eds.) Hvem er villest i landet her? Menneskets brutalitet mot dyr i en verden uten villmark, Scandanavian Academic Press. Oslo, 2013.

Sollund, R. and Maher, J., The Illegal Wildlife Trade: A Case Study Report on the Illegal Wildlife Trade in the United Kingdom, Norway, Colombia and Brazil. A Study Compiled as Part of the EFFACE Project, EFFACE. Oslo, 2015.

South, N., "The contested planet: Global green criminology and environmental crime in transnational context", in T. Spapens, R. White and W. Huisman (eds.), Environmental Crime in Transnational Context, Routledge. London, 2016.

South, N., "Free trade agreements, private courts and environmental exploitation: Disconnected policies, denials and moral disengagement", in International Journal for Crime, Justice and Social Democracy, num 5, 2016.

Strauss, A. and Corbin, J., " Grounded theory methodology", in N. K. Denzin and Y. S. Lincoln (eds.), Handbook of Qualitative Research, Sage. Thousand Oaks, CA, 1994. 
Strauss, S. and Feiz, P., Discourse Analysis: Putting our Worlds into Words, Routledge. London, 2014.

Stoett, P., "The international regulation of trade in wildlife: Institutional and normative considerations", in International Environmental Agreements, num 2, iss 2, 2002.

Trouwborst, A., Blackmore, A., Boitani, L., Bowman, M., Caddell, R., Chapron, G.,...Linnell, J. D. C., "International wildlife law: Understanding and enhancing its role in conservation", in BioScience, num 67, 2017. $<$ doi:10.1093/biosci/bix086>.

Trouwborst, A., Fleurke, F. M. and Linnell, J. D. C., "Norway's wolf policy and the Bern Convention on European Wildlife: Avoiding the 'manifestly absurd'", in Journal of International Wildlife Law and Policy, num 20, 2017.

United Nations, Declaration of the United Nations Conference on the Human Environment, Audio Visual Library of International Law, 1972. $<$ https://legal.un.org/avl/ha/dunche/dunche.html>. [Retrieved on 26 February 2021].

van Uhm, D., The Illegal Wildlife Trade, Springer. New York, 2016.

Vetlesen, A. J., Cosmologies of the Anthropocene: Panpsychism, Animism, and the Limits of Posthumanism, Routledge. London, 2019.

Vetlesen, A. J., The Denial of Nature: Environmental Philosophy in the Era of Global Capitalism, Routledge. London, 2016.

White, R., (ed.), Environmental Crime: A Reader, Willian. Collumpton, UK, 2009.

Williams, C. and Arrigo, B., "Philosophy, crime, and theoretical criminology", in B. Arrigo and C. Williams (eds.), Philosophy, Crime and Criminology, University of Illinois Press. Urbana-Champaign, 2006.

Wolff, J., An Introduction to Political Philosophy, Oxford University Press. Oxford, 2016 (3rd edition). 